\title{
Infertility Specific Quality of Life and Gender Role Attitudes in German and Hungarian Involuntary Childless Couples
}

\author{
Infertilitätsbezogene Lebensqualität und persönliches Geschlechtsrollen- \\ verhalten infertiler Paare in Deutschland und in Ungarn
}

Authors

Affiliations
R. E. Cserepes ${ }^{1}$, A. Bugán ${ }^{1}$, T. Korösi ${ }^{2}$, B. Toth ${ }^{3}$, S. Rösner ${ }^{3}$, T. Strowitzki ${ }^{3}$, T. Wischmann ${ }^{4}$

${ }^{1}$ Department of Behavioural Sciences, University of Debrecen, Debrecen, Hungary

2 Kaáli Institute, Gyor, Hungary

3 Department of Gynaecological Endocrinology and Reproductive Medicine, Women's Hospital, University of Heidelberg, Heidelberg, Germany

${ }^{4}$ Institute of Medical Psychology, Centre for Psychosocial Medicine, University of Heidelberg, Heidelberg, Germany

Key words
infertility
quality of life
gender roles
Germany
Hungary
Schlüsselwörter
Infertilität
Lebensqualität
Geschlechtsrollen
Deutschland
Ungarn

received 27.7.2014 revised $\quad 9.10 .2014$ accepted $\quad 10.10 .2014$

Bibliography

DOI http://dx.doi.org/ 10.1055/s-0034-1383235

Geburtsh Frauenheilk 2014; 74: 1009-1015 @ Georg Thieme Verlag KG Stuttgart · New York ISSN 0016-5751

\section{Correspondence}

Réka Eszter Cserepes, MA

University of Debrecen

Department of Behavioural

Sciences

Nagyerdei krt. 98

4032 Debrecen

Hungary

cserepes.reka@sph.unideb.hu

\section{Abstract}

$\nabla$

Introduction: As gender role attitudes and the evaluation of parenthood and childlessness have subtle variations in each society, cross-country studies focusing on infertility are needed to draw a complex picture in the psychosocial context of infertility. This study investigates similarities and differences between German and Hungarian infertile couples regarding infertility specific quality of life and personal gender role attitudes. Methods: A cross-sectional study was conducted with data of 540 participants (270 couples) attending the first fertility consultation in one fertility clinic in Germany and in five fertility clinics in Hungary. Data were collected between February 2012 and March 2013. Two psychological questionnaires were applied: The FertiQoL to measure infertility specific quality of life and the PAQ to measure gender role attitudes like "instrumental" acting (as a traditional "masculine" attitude) and "expressive" communicating (as a traditional "femine" attitude) and their combinations "combined" attitude (as both "instrumental" and "expressive") and "neutral" attitude (neither "instrumental" nor "expressive").

Results: German couples seeking assisted reproduction treatment are older aged and have longer lasting relationships than Hungarian couples. Hungarian couples scored higher on all quality of life scales than did German couples. In the Hungarian group, "combined" attitudes (use of both "expressive" and "instrumental" attitudes) is associated with higher levels of quality of life compared with other gender role attitudes. In the German group, individuals with "combined" attitudes seem to show better quality of life than those in "expressive" and "neutral" clusters.

Conclusions: The strategy of using combined "expressive" and "instrumental" attitudes proved to act as a buffer against infertility-related stress for both members of the couple in two European

\section{Zusammenfassung \\ $\nabla$}

Einführung: Da Geschlechtsrollenverhalten und die Bewertung von Elternschaft und Kinderlosigkeit in jeder Gesellschaft variieren, sind ländervergleichende Studien zu den psychosozialen Aspekten von Fertilitätsstörungen nötig, um diese komplexen Zusammenhänge abzubilden. In dieser Studie werden gemeinsame und unterschiedliche Aspekte bezüglich infertilitätsbezogener Lebensqualität und persönlichem Geschlechtsrollenverhalten infertiler Paare in Deutschland und in Ungarn untersucht.

Material und Methode: 540 Personen (270 Paare) mit Erstkontakt in einem Kinderwunschzentrum (1 deutsches und 5 ungarische Zentren) nahmen an dieser Querschnittsstudie teil. Die Datenerhebung erfolgte zwischen Februar 2012 und März 2013. Zwei psychologische Fragebögen wurden verwendet: Der FertiQoL zu Erfassung infertilitätsspezifischer Lebensqualität und der PAQ zur Erfassung von Geschlechtsrollenverhalten wie „instrumentell“ handelnd (als traditionell „maskuline“ Verhaltensweise) und „expressiv“ mitteilend (als traditionell „feminine“ Verhaltensweise) sowie deren Kombinationen „kombiniertes“ Verhalten (Gebrauch von sowohl „expressiven“ als auch „instrumentellen“ Verhaltensweisen) und „neutrales“ Verhalten (Gebrauch von weder „expressiven“ noch „instrumentellen“ Verhaltensweisen).

Ergebnisse: Das Alter und die Partnerschaftsdauer lagen bei den deutschen Paaren unserer Studie im Vergleich zu den ungarischen Paaren durchschnittlich höher. Ungarische Paare wiesen höhere Werte auf allen Lebensqualitätsskalen im Vergleich zu den deutschen Paaren auf. In der ungarischen Studiengruppe scheint „kombiniertes“ Verhalten (Gebrauch von sowohl „expressiven“ als auch „instrumentellen“ Verhaltensweisen) mit höherer Lebensqualität zusammenzuhängen, verglichen mit anderen Verhaltensweisen. Bei deut- 
countries and can therefore be recommended as helpful in counselling the infertile couple. schen Studienteilnehmern zeigt „kombiniertes“ Verhaltensweisen einen Zusammenhang mit höherer Lebensqualität, verglichen mit „expressiven“ und „neutralen“ Verhaltensweisen.

Diskussion: Die Strategie des Gebrauchs von sowohl expressiven als auch instrumentellen Verhaltensweisen erwies sich als funktionierender „Puffer“ gegenüber infertilitätsspezifischem Stress für beide Partner in 2 europäischen Ländern und kann daher in der Kinderwunschberatung als hilfreich empfohlen werden.

\section{Introduction}

For many couples, facing infertility is one of the hardest life crises affecting physical and emotional well-being, marital and sexual satisfaction and the quality of other social relations [1-5]. A number of studies emphasizes marked gender differences in psychological response to involuntary childlessness [6-11] although gender role identification could be a better predictor for infertility-related strains than could only gender [12,13]. Berg et al. [12] indicated that "masculinity" correlated with emotional stability and marital satisfaction. Furthermore, infertile women with more "masculine" attitudes are less anxious than women with a "feminine sex-role type" [14]. When gender roles are realized in a more traditional way, it causes more distress for a woman, but not for a man. Positively and negatively valued instrumental ("masculine") attributes in infertile women were described as predictors of lower and higher distress in another study [13]. However, gender role orientation did not predict cognitive appraisals of infertility as stressful and infertility-related distress was neither impacted by "femininity". The role of "feminine" attitudes may not be neglected because other authors emphasized their effect on stress level regarding involuntary childlessness, and women in an infertile group have more "feminine" attributes than women in the general population [15-18]. In addition, desire for a child and consequences of failure to conceive are culturally and socially contingent: the stronger gender roles are internalized, the stronger individuals with infertility problems perceive themselves as defected [1,10,19-24].

In this study, we compare some infertility-related conditions of Hungary and Germany. Analyses based on the Generations and Gender Survey emphasize differences in attitudes towards social aspects like parenting intentions and gender role orientations [25-27]: Hungarians attach more importance to traditional concepts, e.g. in regard to gender roles while women and men in Western regions of Germany share both traditional and egalitarian values. Other studies summarize that individuals from a European but very traditional sociocultural context are more affected by infertility-related emotional strains than those from a less traditional culture $[20,28]$.

This study investigates the unique domains of infertility-related quality of life (QoL) and its relations to gender role attitudes in Germany and Hungary. The aim of the study is twofold.

- Firstly, we want to describe differences in sociodemographic variables, infertility specific quality of life and gender role attitudes in German and Hungarian infertile samples of couples. We hypothesize that strains of infertility are experienced in different ways in these two countries. We expect that Hungarian couples suffer from involuntary childlessness in a greater extent and have worse quality of life than do German couples. At the same time, we suppose that Hungarian individuals follow a more traditional gender role model than Germans, so that "traditional femininity" is of greater value for Hungarian women and "traditional masculinity" for Hungarian men than for their German fellows.

- Secondly, we want to examine the differences concerning infertility-related quality of life among persons with different gender role attitudes. As gender roles and reproduction are strongly linked, it is expected that experiencing infertility is influenced by how individuals think about and incorporate gender role attitudes. In this sense, we hypothesize that expression of emotions ("traditional femininity") decreases the infertilityrelated quality of life and that instrumentality (as a part of "traditional masculinity") has a positive influence on many domains in quality of life.

\section{Methods}

$\nabla$

\section{Study population}

Data was collected in two university-based and in three private fertility clinics in Hungary (Clinic of Obstetrics and Gynaecology University of Debrecen, Department of Obstetrics and Gynaecology Jósa András Teaching Hospital Nyíregyháza, Róbert Károly Private Clinic Budapest, Kaáli Institutes Győr and Budapest) and in one German fertility clinic (Department of Gynecological Endocrinilogy and Fertility Disorders, Ruprecht-Karls University of Heidelberg). All couples attending the first fertility consultation were invited by a medical assistant to take part in the study. Participants had filled out the questionnaire set and signed the consent forms before they saw their reproductive specialist.

Participants were enrolled from February 2012 till April 2013. They had to meet the diagnostic criteria of infertility stated by International Committee for Monitoring Assisted Reproductive Technology [29]: i.e. they had failed to reach pregnancy in a time period of one year or more while having regular, unprotected sexual intercourse. Couples were included if they had sufficient knowledge in Hungarian or in German language according to the place of data collection and had not been treated in the clinic before.

The study received approval from the Scientific and Research Ethics Committee of Health Scientific Board in Hungary and the Ethics Committee of the Medical Faculty of the Ruprecht-Karls University Heidelberg.

\section{Data assessment: infertility specific quality of life}

The infertility specific quality of life was measured using the internationally developed and validated FertiQoL [30]. Its Core module consists of 24 items regarding five domains: Emotional (e.g. "Do you fluctuate between hope and despair because of fertility problems?"), Mind-Body (e.g. "Are your attention and concentration impaired by thoughts of infertility?"), Relational (e.g. "Have fertility problems strengthened your commitment to your partner?"), Social (e.g. "Do you feel your family can understand what you are going through?") and a Global sum scale. In this 
study, German and Hungarian versions of FertiQoL Core were used. Internal consistency on the total scale and the subscales had a good Cronbach reliability statistics ranging 0.63 to 0.88 . Higher scores indicate higher quality of life.

The German version of FertiQoL [31] also contained a self-constructed socio-demographic questionnaire and a medical sheet which were also translated into Hungarian.

\section{Data assessment: gender role attitudes}

The Personal Attribute Questionnaire (PAQ [32,33] German version: GEPAQ [34]) was used to assess personal gender roles attitudes. This is a 16-item measure with two scales to assess desirable instrumental, acting (I scale, e.g. "not at all independent/ very independent") and expressive, communicating (E scale, e.g. "not at all understanding of others/very understanding of others") attitudes, respectively. Personality traits of women and men are not measured. Instrumental traits had been judged to be more characteristic for men (also termed traditional "masculine" attitudes by the PAQ author), but socially desirable for both genders; and expressive traits had been considered to be more characteristic for women (also termed traditional "feminine" attitudes by the PAQ author) [32]. The scales were internally consistent: $\alpha=0.69$ and $\alpha=0.60$, respectively.

\section{Statistical analysis}

Analyses were performed with the use of SPSS for Windows, release 22.0 (Chicago, IL, USA). T-tests were used to calculate differences between German and Hungarian participants in some continuous variables and the scales of FertiQoL and PAQ. T-Tests were performed also for gender differences. As FertiQoL has a correlation with higher level of education [11] what could also determine cross-country QoL-differences, we carried out MANOVA to test main effect and post hoc test for education. In order to identify interdependent correlations between gender role attitudes and quality of life, we constructed a four-fold typology of the two PAQ scales with two-step cluster analysis, resulting in four groups ("combined" = high I and E scores, "instrumental" = high I and low E scores, "expressive" = high E and low I scores, and "neutral" = low I and E scores). In order to find differences among gender role attitude groups, MANCOVA was calculated with FertiQoL scales as dependent variables, gender and education as covariates. Significance level was set at $\mathrm{p}<0.05$.

\section{Results}

\section{Study population}

288 participants (response rate $81 \%$ ) in Germany and 252 participants (response rate $43 \%$ ) in Hungary completed the questionnaire set, thus the initial database was composed of data of 540 participants (270 couples). Some German members who agreed to participate in our study did not fill out either FertiQoL or PAQ, therefore 498 participants (249 couples) were left for final analysis.

Comparing the two study populations regarding age, education level, type of relationship, type of diagnosis, duration of partnership, and duration of child wish, we found that German couples were older and lived for longer in a partnership ( $\bullet$ Table 1 ). More Hungarian participants had higher secondary education and less primary or lower secondary education. Hungarian women also had significant higher education than German women. In the German study population, there was a lower, but still high num-
Table 1 Cross-country differences in socio-demographic and medical characteristics of subjects.

\begin{tabular}{|c|c|c|c|c|}
\hline & \multicolumn{2}{|c|}{$\begin{array}{l}\text { German } \\
\text { subjects } \\
(n=246)\end{array}$} & \multicolumn{2}{|c|}{$\begin{array}{l}\text { Hungarian } \\
\text { subjects } \\
(\mathbf{n}=252)\end{array}$} \\
\hline & M & SD & M & SD \\
\hline Age - women & 34.4 & 4.6 & $32.3^{* *}$ & 4.9 \\
\hline Age - men & 37.9 & 6.3 & $34.5^{* * *}$ & 5.0 \\
\hline Duration of relationship & 8.4 & 5.0 & $7.3^{* *}$ & 3.7 \\
\hline \multirow[t]{2}{*}{ Duration of child wish } & 2.8 & 2.1 & 2.7 & 1.9 \\
\hline & \multicolumn{2}{|l|}{$\%$} & \multicolumn{2}{|l|}{$\%$} \\
\hline \multicolumn{5}{|l|}{ Education - Women } \\
\hline - Primary/lower secondary & \multicolumn{2}{|l|}{48.8} & \multicolumn{2}{|l|}{$17.5^{* * *}$} \\
\hline Higher secondary & \multicolumn{2}{|l|}{14.6} & \multicolumn{2}{|l|}{$31.7^{* *}$} \\
\hline - University & \multicolumn{2}{|l|}{31.7} & \multicolumn{2}{|l|}{$50.8^{*}$} \\
\hline \multicolumn{5}{|l|}{ Education - Men } \\
\hline - Primary/lower secondary & \multicolumn{2}{|l|}{52.8} & \multicolumn{2}{|l|}{$37.3^{*}$} \\
\hline - Higher secondary & \multicolumn{2}{|l|}{15.4} & \multicolumn{2}{|l|}{$31.0^{* *}$} \\
\hline - University & \multicolumn{2}{|l|}{31.7} & \multicolumn{2}{|l|}{31.7} \\
\hline \multicolumn{5}{|l|}{ Diagnosis } \\
\hline - Unexplained/no data & \multicolumn{2}{|l|}{25.0} & \multicolumn{2}{|l|}{$43.7^{* * *}$} \\
\hline V Female only & \multicolumn{2}{|l|}{30.8} & \multicolumn{2}{|l|}{31.7} \\
\hline Male only & \multicolumn{2}{|l|}{26.7} & \multicolumn{2}{|l|}{20.6} \\
\hline - Mixed factor & \multicolumn{2}{|l|}{17.5} & \multicolumn{2}{|l|}{$4.0^{* * *}$} \\
\hline
\end{tabular}

M: mean, SD: standard deviation

* Cross-country difference is significant at level $p<0.05$

** Cross-country difference is significant at level $p<0.01$

*** Cross-country difference is significant at level $p<0.001$

ber of unexplained infertility (or no information about the cause) and there were fewer cases of infertility affecting both partners in Hungarian couples.

\section{Differences between countries and genders:}

Hungarian infertile couples and men show better QoL

Hungarian women and men scored higher on QoL scales than German women and men. Therefore Hungarians seem to feel less burdens of infertility on their emotional, mind/body status and their partnership and other social relations ( $\bigcirc$ Table 2). Hungarian women reported more "expressive" attitudes than German women. Gender differences in the German group were detected only on Emotional and Mind/Body scales. Hungarian women scored lower than men on all FertiQoL subscales except Relational scale. Gender differences were detected on PAQ scales as expected: women showed more "expressive" attitudes, and men showed more "instrumental" attitudes.

We did not find any differences in quality of life in connection with education level in the total study population, but with regard to women, the level of education had some effect on quality of life. Women in the higher secondary education group reported better QoL-scores in each domain than did women with primary or lower secondary education (regarding emotional, social and global domains, female participants with university degree also scored higher than female members of the primary or lower secondary education group) (Data not shown).

\section{Differences in gender role attitudes:}

Having incorporated both "expressive" and

"instrumental" attitudes has a strong correlation with good quality of life

We performed correlations between the dimensions of the two questionnaires to filter possible tendencies for high scoring in 

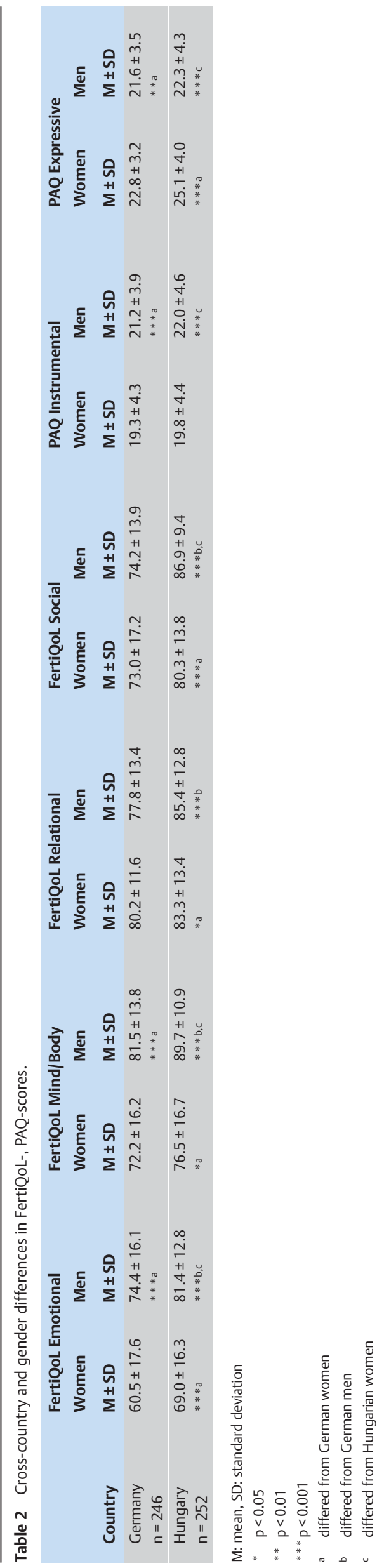

every scale. PAQ scales correlated with FertiQoL scales only in certain cases significantly (Data not shown) so we excluded the high intercorrelation between the scales and we created four distinct PAQ-categories: "combined", "instrumental", "expressive" and "neutral". As stated before, the category "combined" comprises high scores on both scales (instrumental and expressive), category "instrumental" means high scores on the instrumental scale only, category "expressive" means high scores on the expressive scale only and the category "neutral" comprises low scores on both scales (instrumental and expressive).

Participants in the "neutral" and "expressive" group tended to show poorer quality of life than subjects with "combined" attitudes in the German group ( $\boldsymbol{O}$ Fig. $\mathbf{1}$ ). These differences were especially accentuated on the FertiQoL Emotional, Mind-Body and Social scales. Individuals with "neutral" attitudes reported additionally a lower level of mind/body quality of life than members of the "instrumental" group. In relational domain, participants with "neutral" scored lower than individuals in all three other groups.

It was remarkable that Hungarian individuals in the "expressive" category seemed to be on the lowest level of quality of life compared with the "combined" group ( $\boldsymbol{\bullet}$ Fig. 2). On all four QoL scales, belonging to the "combined" group was associated with the highest scores concerning the Hungarian sample. Even participants with "instrumental" and "neutral" attitudes reported about lower relational and social quality of life than members of the "combined" cluster.

\section{Discussion}

The most important finding of the present study is the connection between gender role attitudes and infertility specific quality of life. Our second hypothesis that "expressive" attitudes are associated with poorer quality of life and "instrumental" attitudes correlate with better quality of life was not confirmed. We conducted the analysis with gender role attitude groups in a more complex way using a four-fold classification of gender role attitudes.

"Combined" attitudes (that means having incorporated both "expressive" and "instrumental" attitudes) tend to have a strong correlation with good quality of life in all areas affected by infertility in both Germany and Hungary. The central finding of our study is that flexibility in the gender role attitudes ("combined" attitudes) might act as a buffer against infertility-related stress for both members of the couple. Similar results have not been found yet in infertile subjects [12,14], but higher level in mental health was proven to be supported by "combined" role attitudes in general populations [35-38].

Subjects with "expressive" role attitudes tend to be the sensitive for psychosocial consequences of infertility. This type of gender role categories is connected with low QoL in Hungarian couples in all domains. In the Hungarian group, our hypothesis was supported completely in that "expressive" attitudes were associated with expression of negative emotions and other burdens evoked by involuntary childlessness. This result is notable because at this point we can find a complex and strong link between burdens of infertility and sensitivity of subjects with "expressive" attitudes that may be determined through strong cultural values of expressivity of emotions and handling problems regarding transition to parenthood. 


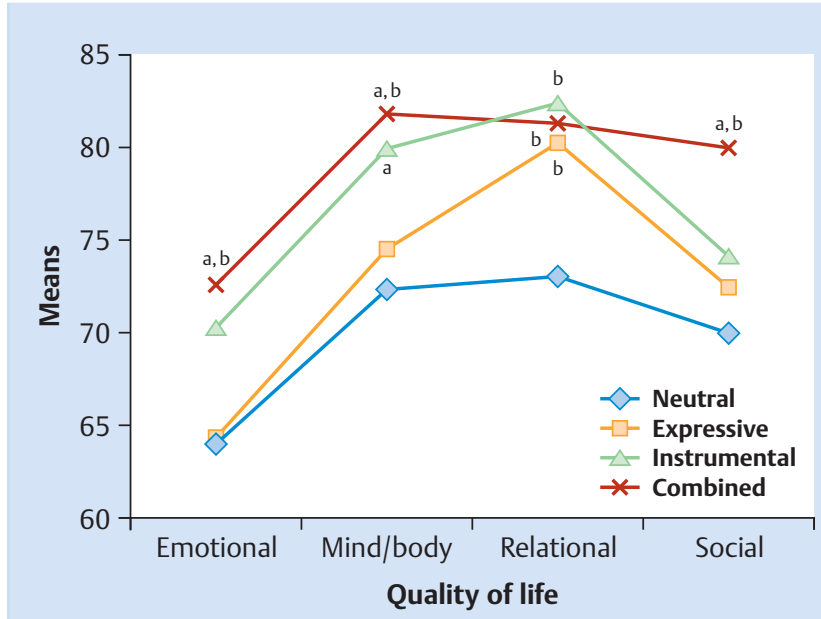

Fig. 1 FertiQoL scores (corrected by gender and education) and gender role attitude categories in the German group. ${ }^{\mathrm{a}}$ significantly differed from expressive group at level $p<0.05,{ }^{b}$ significantly differed from neutral group at level $p<0.05$.

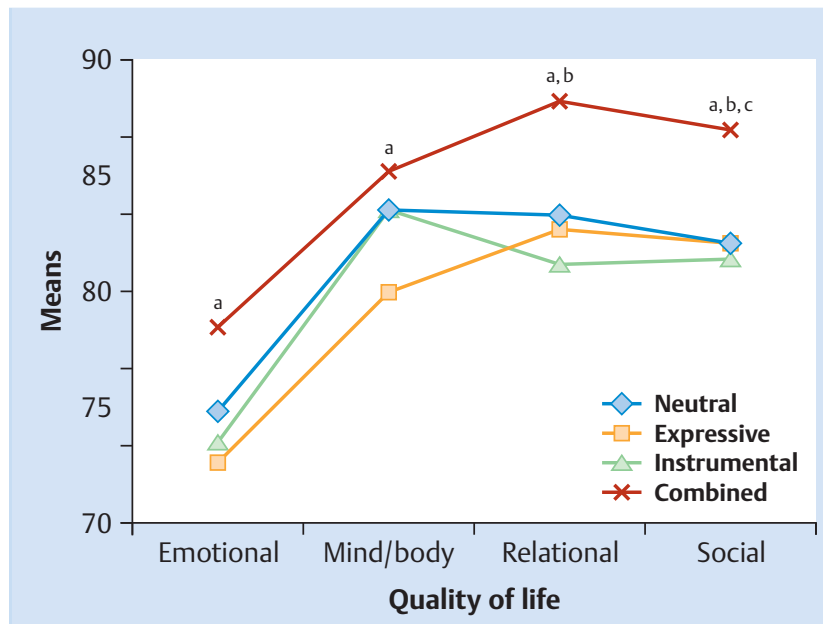

Fig. 2 FertiQoL scores (corrected by gender and education) and gender role attitude categories in the Hungarian group. ${ }^{\text {a }}$ significantly differed from expressive group at level $p<0.05$, b significantly differed from instrumental group at level $p<0.05,{ }^{c}$ significantly differed from neutral group at level $\mathrm{p}<0.05$.
However, German participants with "neutral" gender role attitudes report also lower levels of quality of life than members of "instrumental" and "combined" cluster. Regarding German individuals who attribute themselves neither "expressive" nor "instrumental" role attitudes may have more problems to create a confident identity. "Neutral" gender role attitudes correlate with greater anxiety and distress in such a gender role specific topic like infertility $[14,39]$.

Several couples with higher levels of education were found in the study (41.3\% in Hungarian, 34.2\% in German group). However, our results do not correspond to the representation of persons with university degree in the general population of both countries $[40,41]$. This share is in line with recent results that high education is positively associated with lifetime fertility intentions in women in Europe $[26,42]$. However, the increasing number of women and men with non-academic educational level in our study - compared with reports of recent studies in German and Hungarian samples of involuntary childless couples [16,43-45] is indeed impressive because it suggests that information about fertility treatments is more widely available and more individuals with lower education, supposedly with less financial sources, can afford to start an assisted reproduction treatment (ART).

Our hypothesis that Hungarian couples had a poorer quality of life because of a stronger identification with traditional gender roles did not tend to be proven. However, Hungarian women had more self-reported "expressive" attitudes than German ones. Although this difference was significant for women our hypothesis that a more traditional gender role model is more present in Hungarians was only partly confirmed. Surprisingly, Hungarian couples rated quality of life regarding infertility-related domains higher than did their German counterparts. In interpretation of these results, we consider that factors from other parts of life and/or medical treatment could enhance the quality of life that was not accurately considered in our study design. Generally, the presence of an appreciative social environment, including supportive medical staff leads to better psychological well-being $[4,46]$. Moreover, perceived social support decreases the infertility-specific stress in personal and relational level [47]. On the other hand, the importance of social expectations may play a role in higher quality of life than expected in the case of Hungarian respondents [16]. Another interpretation could be that the high educational status of Hungarian women (compared to German women) could indirectly increase QoL of the couple because a potential satisfying work situation might offer an alternative life goal if ART should fail. In addition, gender role expectations may have changed even recently [26].

To the best of our knowledge, this is the first study measuring self-reported gender role attributes in the field of infertility conducted in two different countries. This study adds new information to the literature focusing on the close relations between gender roles and infertility.

A main strength of the study is that it broadens the literature of infertility with psychosocial approach in Central and Eastern Europe. Only a few recent studies investigated relevant topics, for instance couples' general experiences of infertility in a traditional milieu, infertile women's gender role attitudes, sexual adjustment and feelings of stigmatization in this region [17,48-50]. In addition, there is an expressed need in the literature for investigating infertility-specific psychosocial aspects in different sociocultural contexts [51].

We used a disease-specific questionnaire in order to get a picture of the infertile couples' experiences covering all substantive problems. As the FertiQoL was developed internationally, it is a proper measurement to detect cross-country differences.

Our focus was mainly on gender related attributes, so other, perhaps important variables such as personality traits, general wellbeing, or self-coherence were not taken into account. We also did not calculate with medical diagnosis because the rate of unexplained infertility and no data about the cause was too high in the sample what could have resulted in biased differences.

The number of participants is satisfactory $(n=540)$, but a relatively low response rate in the Hungarian group (43\%) may have influenced the results through selection bias. This fact means that a significant part in that group did not want to participate in research or is not open to speak about their infertile status. We may only suppose that non-responding individuals have more prob- 
lems to cope with infertility, but seclusion and secrecy to distant relationships could make them adjust easier to involuntary childlessness [47]. On the other hand, the data of German couples were collected only in one fertility centre which can lead to contraselected results. In order to get more representative results, it would be desirable to expand the study and involve additional fertility clinics.

\section{Conclusions for Practice \\ $\nabla$}

Medical staff should give patients more information about links between gender associated attitudes and experiencing difficulties when trying to become a parent. In psychosocial infertility counselling for individuals or for couples, professionals could accentuate the topic of gender roles and encourage flexibility in living them, developing a kind of "combined" strategy to cope with the burden of infertility. This strategy of combined "expressive" and "instrumental" attitudes proved to act as a buffer against infertility-related stress for both members of the couple in two European countries and therefore it can be recommended to infertile couples in infertility counselling.

\section{Acknowledgements \\ $\nabla$}

We are grateful to the German and Hungarian women and men who agreed to participate in this study.

We would like to thank the staff in all participating fertility clinics for their help in collecting data.

\section{Funding}

$\nabla$

This publication was based on REC's research, which was supported by the European Union and the State of Hungary, co-financed by the European Social Fund in the framework of TÁMOP-4.2.4.A/2-11/1-2012-0001 “National Excellence Program”.

\section{Conflict of Interest}

$\nabla$

The authors report no conflicts of interest.

\section{References}

1 Whiteford LM, Gonzalez L. Stigma: the hidden burden of infertility. Soc Sci Med 1995; 40: 27-36

2 Wischmann TH. Sexual disorders in infertile couples. J Sex Med 2010; 7: $1868-1876$

3 Wischmann T. Sexual disorders in infertile couples: an update. Curr Opin Obstet Gyn 2013; 25: 220-222

4 Lund R, Sejbaek CS, Christensen $U$ et al. The impact of social relations on the incidence of severe depressive symptoms among infertile women and men. Hum Reprod 2009; 24: 2810-2820

5 Chachamovich JR, Chachamovich E, Ezer $\mathrm{H}$ et al. Investigating quality of life and health-related quality of life in infertility: a systematic review. J Psychosom Obstet Gyn 2010; 31: 101-110

6 Jordan C, Revenson T. Gender differences in coping with infertility: a meta-analysis. J Behav Med 1999; 22: 341-358

7 Holter $H$, Anderheim L, Bergh C et al. First IVF treatment-short-term impact on psychological well-being and the marital relationship. Hum Reprod 2006; 21: 3295-3302

8 Wischmann T, Stammer H, Scherg H et al. Psychosocial characteristics of infertile couples: a study by the 'Heidelberg Fertility Consultation Service'. Hum Reprod 2001; 16: 1753-1761
9 Thompson E, Woodward J, Stanton A. Dyadic goal appraisal during treatment for infertility: how do different perspectives relate to partners' adjustment? Int J Behav Med 2012; 19: 252-259

10 Hjelmstedt A, Andersson L, Skoog-Svanberg A et al. Gender differences in psychological reactions to infertility among couples seeking IVF- and ICSI-treatment. Acta Obstet Gyn Scan 1999; 78: 42-48

11 Huppelschoten AG, van Dongen AJ, Verhaak CM et al. Differences in quality of life and emotional status between infertile women and their partners. Hum Reprod 2013; 28: 2168-2176

12 Berg BJ, Wilson JF, Weingartner PJ. Psychological sequelae of infertility treatment: the role of gender and sex-role identification. Soc Sci Med 1991; 33: 1071-1080

13 Miles LM, Keitel M, Jackson $M$ et al. Predictors of distress in women being treated for infertility. J Reprod Infant Psych 2009; 27: 238-257

14 Cook $R$. The relationship between sex role and emotional functioning in patients undergoing assisted conception. J Psychosom Obstet Gyn 1993; $14: 31-40$

15 van Balen F, Trimbos-Kemper TC. Long-term infertile couples: a study of their well-being. J Psychosom Obstet Gyn 1993; 14: 53-60

16 Cserepes RE, Kollar J, Sapy T et al. Effects of gender roles, child wish motives, subjective well-being, and marital adjustment on infertility-related stress: a preliminary study with a Hungarian sample of involuntary childless men and women. Arch Gynecol Obstet 2013; 288: 925932

17 Bidzan M, Podolska M, Bidzan L et al. [Personality traits and the feeling of loneliness of women treated for infertility]. Ginekol Pol 2011; 82: 508-513

18 van Balen F, Trimbos-Kemper T. Factors influencing the well-being of long-term infertile couples. J Psychosom Obstet Gynaecol 1994; 15: 157-164

19 Greil AL, Slauson-Blevins K, McQuillan J. The experience of infertility: a review of recent literature. Sociol Health Ill 2010; 32: 140-162

20 Vanderlinden $L K$. German genes and Turkish traits: Ethnicity, infertility, and reproductive politics in Germany. Soc Sci Med 2009; 69: 266-273

21 Johnson KM, Fledderjohann J. Revisiting "her" infertility: Medicalized embodiment, self-identification and distress. Soc Sci Med 2012; 75: 883-891

22 Domar A, Gordon K, Garcia-Velasco J et al. Understanding the perceptions of and emotional barriers to infertility treatment: a survey in four European countries. Hum Reprod 2012; 27: 1073-1079

23 Connolly KJ, Edelmann RJ, Cooke ID et al. The impact of infertility on psychological functioning. J Psychosom Res 1992; 36: 459-468

24 Mikkelsen AT, Madsen SA, Humaidan P. Psychological aspects of male fertility treatment. J Adv Nurs 2013; 69: 1977-1986

25 Pongrácz T, Murinkó L. Division in Household Labour. Similarities and Differences in Europe. In: Nagy I, Pongrácz T, eds. Changing Roles: Report on the Situation of Women and Men in Hungary. [In Hungarian]. Budapest: TÀRKI Social Research Institute; 2009: 95-116

26 Pongrácz TS, Molnár E. Interaction of Gender Roles and Changes in public Opinion. In: Nagy I, Pongrácz T, eds. Changing Roles: Report on the Situation of Women and Men in Hungary. [In Hungarian]. Budapest: TÀRKI; 2011: 192-206

27 Vikat A, Spéder Z, Beets G et al. Generations and Gender Survey (GGS): towards a better understanding of relationships and processes in the life course. Demogr Res 2007; 17: 389-440

28 van Rooij FB, van Balen F, Hermanns JMA. Emotional distress and infertility: Turkish migrant couples compared to Dutch couples and couples in Western Turkey. J Psychosom Obstet Gyn 2007; 28: 87-95

29 Zegers-Hochschild F, Adamson GD, de Mouzon J et al. The International Committee for Monitoring Assisted Reproductive Technology (ICMART) and the World Health Organization (WHO) Revised Glossary on ART Terminology, 2009. Hum Reprod 2009; 24: 2683-2687

30 Boivin J, Takefman J, Braverman A. The Fertility Quality of Life (FertiQoL) tool: development and general psychometric properties. Fertil Steril 2011; 96: 409.e3-415.e3

31 German Associated FertiQoL-Study. 2011. Online: http://www.fertiqol. de/; last access: 08.10.2011

32 Spence JT. Gender-related traits and gender ideology: evidence for a multifactorial theory. J Pers Soc Psychol 1993; 64: 624-635

33 Gervai J, Turner PJ, Hinde RA. Gender-related behaviour, attitudes, and personality in parents of young children in England and Hungary. Int J Behav Dev 1995; 18: 105-126

34 Buddeberg-Fischer B, Klaghofer R, Abel T et al. The influence of gender and personality traits on the career planning of Swiss medical students. Swiss Med Wkly 2003; 133: 535-540 
35 Bem SL. The measurement of psychological androgyny. J Consult Clin Psychol 1974; 42: 155-162

36 Priess HA, Lindberg SM, Hyde JS. Adolescent gender-role identity and mental health: gender intensification revisited. Child Dev 2009; 80: 1531-1544

37 Gale-Ross R, Baird A, Towson S. Gender role, life satisfaction, and wellness: androgyny in a southwestern Ontario sample. Can J Aging 2009; 28: $135-146$

38 Lipińska-Grobelny A. Effects of gender role on personal resources and coping with stress. Int J Occup Med Environ Health 2011; 24: 18-28

39 Koropatnick S, Daniluk J, Pattinson HA. Infertility: a non-event transition. Fertil Steril 1993; 59: 163-171

40 Hungarian Statistical Central Office. Education, language knowledge. [In Hungarian]. 2011. Online: http://www.ksh.hu/nepszamlalas/tablak_teruleti_00; last access: 16.08.2013

41 German Statistical Federal Agency. Education, research, culture. [German]. 2012. Online: https://www.destatis.de/DE/ZahlenFakten/GesellschaftStaat/BildungForschungKultur/Bildungsstand/Tabellen/ Bildungsabschluss.html; last access: 16.08.2013

42 Testa MR. On the positive correlation between education and fertility intentions in Europe: Individual- and country-level evidence. Adv Life Course Res 2014; 21: 28-42

43 Herrmann D, Scherg H, Verres $R$ et al. Resilience in infertile couples acts as a protective factor against infertility-specific distress and impaired quality of life. J Assist Reprod Gen 2011; 28: 1111-1117
44 Schilling $K$, Toth B, Rosner $S$ et al. Prevalence of behaviour-related fertility disorders in a clinical sample: results of a pilot study. Arch Gynecol Obstet 2012; 286: 1307-1314

45 Wischmann T, Scherg H, Strowitzki T et al. Psychosocial characteristics of women and men attending infertility counselling. Hum Reprod 2009; 24: 378-385

46 Aarts JW, Huppelschoten AG, van Empel IW et al. How patient-centred care relates to patients' quality of life and distress: a study in 427 women experiencing infertility. Hum Reprod 2012; 27: 488-495

47 Martins MV, Peterson BD, Costa P et al. Interactive effects of social support and disclosure on fertility-related stress. J Soc Pers Relat 2012; 30: 371-388

48 Drosdzol A, Skrzypulec V. Quality of life and sexual functioning of Polish infertile couples. Eur J Contracep Reprod 2008; 13: 271-281

49 Slepičková L. Couples undergoing infertility treatment in the Czech Republic: Broad range of possibilities in a traditional milieu. Soc Theory Health 2010; 8: 151-174

50 Todorova IL, Kotzeva T. Social discourses, women's resistive voices: facing involuntary childlessness in Bulgaria. Women Stud Int Forum 2003; 26: 139-151

51 Culley L, Hudson N, Lohan M. Where are all the men? The marginalization of men in social scientific research on infertility. Reprod Biomed Online 2013; 27: 225-235 